\title{
The Effect of Social Media on Sports Marketing: Konyaspor Football Club Case*
}

\author{
Esen ŞAHIN iD a M. Tahir DEMIRSEL iD b Abdullahi Ahmed ADAM iD c \\ a Selcuk University, Konya, Turkey. esenboztassahin@gmail.com \\ b Selcuk University, Konya, Turkey mtdemirsel@hotmail.com \\ c Istanbul University, İstanbul, Turkey scholarcabdalla@hotmail.com
}

\begin{tabular}{|c|c|}
\hline ARTICLE INFO & ABSTRACT \\
\hline Keywords: & Purpose - The objective of this study is to examine the effect of social media on sports marketing. \\
\hline Social Media & \multirow{8}{*}{$\begin{array}{l}\text { Design/methodology/approach - The data of this research have been collected through } \\
\text { questionnaire method. The research population was formed by the followers of the club's social } \\
\text { media pages. In this context, there are about } 228.000 \text { people who liked the club's Facebook account; } \\
\text { and also there are about } 150.000 \text { people following the Twitter account. The club's population was } \\
\text { determined from the number of followers on the Facebook page. } 384 \text { questionnaires was distributed } \\
\text { to the fans. Statistical Package for Social Science (SPSS) } 23.0 \text { was used to analyze the data obtained } \\
\text { from the survey. Reliability, Frequency Distribution, Mean Standard Deviation, KMO and Barlett } \\
\text { Test, Factor Analysis, Correlation and Regression Analyzes were performed by determining the } \\
\text { statistical tests to be used in the data analysis when the data were coded. The Cronbach alpha } \\
\text { coefficient was used to determine the reliability of the scales included in the survey form. }\end{array}$} \\
\hline Social Media Marketing & \\
\hline Sports Marketing & \\
\hline & \\
\hline Consumer Behavior & \\
\hline Received 16 October 2019 & \\
\hline Revised 30 December 2019 & \\
\hline Accepted 5 Februa & \\
\hline \multirow{4}{*}{$\begin{array}{l}\text { Article Classification: } \\
\text { Research Article }\end{array}$} & $\begin{array}{l}\text { Findings - According to the findings, there is a positive and significant relationship between getting } \\
\text { information from social media channels of Konyaspor Football Club and fans' consuming behavior }\end{array}$ \\
\hline & tendency. According to the results of the hypothesis tests, there is a positive and significant \\
\hline & $\begin{array}{l}\text { relationship between "Getting Information, Communication, Sharing with, Perception of Supporter, } \\
\text { Spending Time factors and Club Licensed Product Preferences Tendency" factors. }\end{array}$ \\
\hline & $\begin{array}{l}\text { Discussion - According to the results of the research, Konyaspor Football Club actively uses social } \\
\text { media accounts to communicate more effectively with its supporters. According to the results of } \\
\text { focus groups and surveys conducted with the fans, it is possible to get information about the team's } \\
\text { existing or new sales products, to get information about matches and tickets, to communicate with } \\
\text { the clubs and footballers and to follow the transfer news. They follow the social media accounts of } \\
\text { the club in order to reach the information and to reach the comments made about the club. } \\
\text { Investigations can then be conducted on the supporters of the different teams in order to better } \\
\text { understand the motivation of the followers for social media teams for subsequent research. A more } \\
\text { thorough investigation can reveal more lasting and effective results by examining and following the } \\
\text { fans' social media data. }\end{array}$ \\
\hline
\end{tabular}

\section{INTRODUCTION}

Sport nowadays is accepted as an activity that people are more interested in to have fun and to live a healthier life. Infrastructure investments made in different sports branches and public service broadcasting encouraging people to be interested in sports make a sport consciousness in the society. This awareness has allowed more people to participate in sports activities and has made the sports industry a big one. Sports brings people from different cultures together without discrimination by age, race or religion. Thanks to the unifying nature of sports, people support teams in countries that they have never visited despite their lives in different cultures and countries, and they have an emotional connection with them. In this respect, individual players as well as teams that are successful in the different sports branches provide important economic contribution to both their own

"This article is the adapted full text version of the paper named "Examining Fans' Behaviors in the Relationship Between Social Media and Sports Marketing: Konyaspor Football Club Case" which was presented orally and published as abstract in the "5th International Conference on Business and Economics Studies" held in New York between 10-12 August 2018.

\section{Suggested Citation}

Şahin, E., Demirsel, M. T., Adam, A. A. (2020). The Effect of Social Media on Sports Marketing: Konyaspor Football Club Case, Journal of Business Research-Turk, 12 (1), 79-94 


\section{E. Şahin - M. T. Demirsel - A. A. Adam 12/1 (2020) 79-94}

countries and other countries. Communication networks that play a role in the formation of this interaction are publishing sports programs for hours and contributing to sport in becoming a social activity.

There is an undeniable influence of communication and marketing when sports become such an effective activity. Thanks to the communication channels, sports organizations and encounters meet the fans and increase the attention on the sports. Social media platforms, which are the most preferred communication channels in recent years, have enabled this attention to come to the fore. The two-way and fast communication of social media has created a more interactive and effective communication environment between fans and sports clubs. Through social media platforms, clubs have the opportunity to learn the habits, motivations, values, wishes and complaints of the fans; and the fans have the opportunity to communicate directly with the teams and athletes they support.

Sports organizations and organizations encourage supporters to communicate and interact with the players, the club's licensed products and sponsors. In addition to this, it is observed that clubs have started to use social media channels as an effective marketing tool when communicating with both stakeholders and fans. Through social media platforms, clubs can advertise and sell tickets and licensed products, and they can make economic contributions both to the club and to the industry.

In this context, it is necessary to research the effects of social media on the sports industry. Therefore the objective of this study is to examine the effect of social media on sports marketing.

\section{LITERATURE REVIEW}

\subsection{The Concepts of Sport and Sports Industry}

Sports are all activities that provide fun for the people. It is also made to become and stay healthy and spend time by most of the people. At the same time, sports can be regarded as a business (Pedersen and Thibault, 2014: 6). Sport is an activity that provides physical and mental development with its own rules (Pitts, et al., 1994: 18), in which people participate individually or as a team (Ekmekci, 2007: 8). Persons can be directly involved in sports activities as participants or spectators. Participants who are included as spectators can be called as sports consumers.

Sports can be considered as an industry that is attracting interest and billions of dollars today as it was in the past (Argan and Katirci, 2015: 3-5). The features such as time spent and enjoyment of the sport have made participation very intense. So much so that sports became such a big industry thanks to the social participation behind it (Altunbaş, 2007: 93). Furthermore, it has been an attractive economic activity for the sporting activities, organizations and sports areas (Rein, et al., 2007: 9), Increasing interest of the media and investors (Devecioğlu, 2005: 118) and the rise in the watching ratio has led to product promotion and advertisements being associated with sports and the sports industry has gained a completely different dimension. Increased participation in sports organizations both as a spectator and as a professional, as well as an increase in the number of publications in the media and the increase in the number of employees in the industry have allowed the sports industry to gain another dimension (Shank and Lyberger, 2015: 13-16).

Some of the features of the sports industry are as follows (Argan and Katirci, 2015: 4):

- A participating industry.

- Provides the opportunity to be identified.

- The organization of the necessary events for the sport; facilities, tools and equipments.

- Contributes to the promotional activities of the sports clubs.

Apart from these characteristics, it is obvious that the sport industry has three components. These include organizing the sport itself, producing sport-related products, and selling sports-related products (Pedersen and Thibault, 2014: 13). Besides these, the promotion and marketing of products other than sports products are carried out through sports events. This has led to the intensive use of sports marketing by both sports clubs, organizers and businesses in non-sports areas and by different sectors. 


\subsection{Sports Marketing}

Although sports marketing is a new field in marketing, sports have been used as a marketing instrument for a long time. However, in 1978 the concept of sports marketing was used for the first time in the Advertising Age magazine. The magazine used this idea to describe the client's activities and the use of sports, which are increasingly the means of promoting the marketing of industrial products and services (Argan and Katirci, 2002: 22).

Developments in the sports industry, especially those following the sports to find billions, to fulfill the wishes of this kitten, and other sectors to reach this audience through sports, sports marketing concept was born (Shilbury, et al., 2009: 14). After that date, sports marketing has received different definitions as seen and used in different areas. So sports marketing can be defined in different ways. (Shilbury, et al., 2009: 14, Milne and McDonald, 1999: 3).

Sports marketing is the process of marketing sports goods, services and other products through sports organizations by the application of marketing concepts (Smith, 2008: 3) and the overall activities to satisfy sports consumers' needs and desires (Mullin, et al., 2000: 8-9). According to another definition, sport marketing is the process of development and implementation of sporting products' production, pricing, distribution and promotional activities (Schwarz and Hunter, 2008: 14).

According to the definitions provided in the literature, it can be said that three factors related to sport marketing have come to the fore. Based on these factors, sports marketing can be explained by three different marketing objectives. These objectives are the marketing and participation of the sport or organization itself, the marketing of sporting goods, and the marketing of non-sporting goods through sports.

This information can be defined as the process of activities in which the needs of sports fans and consumers can be met by using marketing strategies of sports marketing, sports organizations, sports products, and non-sports goods and services. According to Shank and Lyberger (2015: 5), sports marketing is the whole set of activities and processes that enable traditional marketing principles to market sporting goods and some other goods by linking them with sports. In this context, sports marketing can be evaluated in two different contexts. In the first, sports marketing is a process developed to satisfy the demands of sports consumers. While these needs may be concrete products such as sportswear and they may be abstract products such as participation in sports organizations, monitoring, and entertainment. The second is the introduction of sports and non-sports areas of products and services. For example, a person watching a sporting event on the television screen sees advertisements for beer, cars and many other types of products (Mullin, et al., 2000: 13).

Finding billions of spectators in the sports allows businesses to reach a massive consumer base through sports organizations. Businesses can advertise their products through sports to reach this audience. Also, sponsorship agreements can be made to create public relations and brand image. In addition, sports investment in different business areas such as investing in sports clubs, sponsorship agreements; desire to gain prestige and image are also in the field of sports marketing (Ekmekçi ve Ekmekçi, 2010: 26).

\subsection{Consumer in Sports}

Sports consumer behavior is the whole of the activities of selecting, receiving and consuming individual sports products or services (Shilbury, et al., 2009: 43). Sports consumers are generally defined as fans. Fans can be described as enthusiastic fanatics who devote themselves to consuming a specific sporting product (Hunt, et al., 1999: 440; Wakefield, 2007: 4).

Sports consumers are segmented according to their motivation, perception and behavior. They develop these behaviors according to their experiences and interests (Pedersen and Thibault, 2014: 320). Therefore, motivation of participation of individuals may vary. Given the personal characteristics, different types of sports have different participants and followers (Goldstein, 1989: 176). 


\section{E. Şahin - M. T. Demirsel - A. A. Adam 12/1 (2020) 79-94}

In the literature, sports consumers are divided into two groups as participants and observers (Schwarz and Hunter, 2008; Pedersen and Thibault, 2014; Shilbury, et al., 2009: Shank and Lyberger, 2015). On the other hand, Smith has divided the sports consumer into four groups. The first group directly buy the sporting goods, materials, newspapers, magazines, etc; the second group purchases sports services; the third group participates directly in sports organizations; and the last group consists of fans and spectators. In addition to these consumer groups, businesses that purchase sporting goods and purchase sports broadcasting rights can also be considered as sports consumers.

\subsection{The Concept of Social Media}

Social media is a phenomenon that has transformed the interaction and communication of individuals throughout the World (Edosomwan, et al., 2011). Social media is characterized as a group of Internet-based applications based on the ideological and technological foundations of Web 2.0, and it provides users with creation and exchange of content on any topic (Kaplan and Haenlein, 2010: 59). It is accepted that social media is an important means of communication regarding both individual users and enterprises, especially in the last 10 years as a result of the developments in technology and new approaches in consumer behavior (Akkaya and Zerenler, 2017: 946).

Social media is the term often used to refer to new forms of media that involve interactive participation. The fact that social media is so important has led to many researches and definitions about the subject. According to Manning (2014: 1158) social media is the term often used to refer to new forms of media that involve interactive participation. According to another definition, social media are internet based tools that lets people to share or exchange informations, ideas, media and even more with each other through a particular network (Siddiqui and Singh, 2016: 71). Social media is also a collection of online tools that allow Internet users to collaborate on content, share experiences and ideas, and come together for fun and business (Strauss and Frost, 2009: 32).

It is seen that most of the definitions made about social media are based on the desire of people to communicate and share. A conclusion that can be drawn from here is; social media is preferred by individual users to satisfy the need for socialization, which is one of the basic needs of man. In this context, social media is a media tool that is developed to satisfy people's need for socialization.

Safko (2012: 4) described social media as "social" and "media", which are two components of the concept. According to Safko, social is the need to communicate with other people whose instinctive motivation is people, while the media is the means we use to communicate. Social media is the use of technologies that enable people to communicate with others, develop relationships, build mutual trust and exchange. Social media technologies play a mediator role in transforming commercial relations into traditional modes of business (Chui, et al., 2012: 35). When this definition is examined, it is seen that commercial aspects of social media are emphasized besides communication and sharing. Particularly nowadays, as the use of social media among consumers increases, it can be easily seen that businesses use social media as a trade, communication, customer relations, public relations and marketing channel.

Social media allows users to access and share information. As a new means of communication, social media enables consumers to create and share content and inform each other about products, services, and brands (Blackshaw and Nazzaro, 2006: 1-2). Social media is a marketing strategy that plays an active role in all phases of the consumer buying process. Users are more confident in the information provided by other consumers than those coming from businesses (Chi, 2011: 56). Social media plays an important role in enabling consumers to share their experience about products and services with other users and to change their purchasing decision before purchasing the product (Divol, et al., 2012).

While consumers' information resources consisted solely of information provided by brands, the development of social media and the increased sharing of information provided increased the resources. In particular, user-based content, oral marketing via the Internet, and viral marketing have become key marketing strategies enabling rapid sharing of this information. 


\subsection{Social Media Marketing}

The growth of social media instruments has led to a major paradigm shift in how marketing experts communicate with consumers around the world (Johnston, et al., 2018: 43). Therefore, as the number of users of social media platforms increases, Social Media Marketing has been born as an alternative way to the traditional marketing. Since social media encourage two-way communication, they are very beneficial relationship-building tools for the marketing experts who chooses to use them to interact with and engage customers (Achen, 2017: 33). Social Media Marketing is a tool that allows businesses and brands to communicate with consumers faster, cheaper and more interactively. According to a more general definition, Social Media Marketing is a process that allows businesses to reach out to more people by using social networks, communities, blogs and other social media tools to promote their products and services (Neti, 2011: 2).

The basic benefit that social media offers to its users is to improve communication. Consumers can make comments and criticisms on platforms about products and services and interact with other users and brands. The brands that are aware of this opportunity are also starting to use social media as an effective communication and promotion tool. Studies that have evaluated Social Media Marketing as a medium of communication in the literature have defined it as a new promotional tool (Mangold and Faulds, 2009: 358) as well as being a new marketing strategy and a set of applications to support traditional marketing. Businesses can use the Social Media Marketing for a variety of purposes (Tuten, 2008: 56):

- Creating brand awareness.

- Ensuring the integration of media.

- Investigating consumer behaviors.

- Developing new marketing strategies.

- Providing the display of the institutional website.

- Increasing product sales and brand image.

\subsection{Sports Marketing Communication in Social Media}

The rapid, mutual and interactive communication presented to social media users has found a vast area of application in the sports industry. Today, sport fans and supporters -actually anybody interested in a sport branch- can easily develop unique and engaging relationships with their favorite sports clubs, both offline and online (Vale and Fernandes, 2018: 37). Especially social mobile platforms are very attractive to an engaging group of media consumers: sports fans as a content delivery platform that also serves social functions (Chan-Olmsted and Xiao, 2019: 181). Although in the social media, engaging with fans, supporters and other stakeholders can be very challenging for a sport organization, it is an extremely worthwhile platform to use beneficial activities (Naraine, 2019: 222). According to Rothschild (2011: 147-148), the sports industry is taking the place of social marketing as a traditional marketing concept. The popularity of social media platforms has led sports organizations, clubs and athletes to use social media. In this respect, the athletes and clubs can communicate with the supporters faster, advertise their products, sell tickets and increase their loyalty to fans' teams with campaign tools. Social media offers sports clubs and organizations the opportunity to reach a wide range of supporters at low cost, to interact and to provide brand awareness (Wysocki, 2012: 9). Thanks to social media, sports clubs and organizers should consider their fans not only as consumers but also as partners, intermediaries and impressive factors at the same time and build strong relationships (Williams and Chinn, 2010: 427).

Social media platforms have gained the opportunity to communicate quickly and interactively with sports clubs and sports fans. Both clubs and supporters share and interact with clubs or athletes. Fans can easily communicate their wishes and criticisms, and develop products and services for these desires and criticisms, taking into account the sharing of club supporters (Hambrick and Kang, 2014: 4). Additionally, in an environment where the media increasingly influence sports consumers, clubs that use social media as a marketing tool can gain a competitive advantage (Thompson, et al., 2014: 44). 


\section{METHODOLOGY}

In the study, this section presents a detailed description of the research methodology, data analysis and findings. Research methodology includes a description of the research design, sampling techniques, and instrumentation. Data analysis section covers analysis techniques and hypothesis testing. This chapter explains how the data was collected, analyzed and what techniques were used.

\subsection{Purpose of the Study}

Social media platforms are viewed as the most preferred communication channels for users today. Since they have more than 2 billion users around the world, businesses and brands in different industries use tools to build better relationships with consumers, learn about their experiences and reach their wishes and complaints. The sports industry is also a supporter of social media; in other words, people who use it to communicate with consumers. Because of this business reality, social media has become the new and most effective communication channel that forms the basis of many researches. In this context, the objective of this study is to examine the effect of social media on sports marketing.

\subsection{Scope of the Study}

The scope of the research is the Konyaspor Football Club and its supporters. Konyaspor Football Club is one of the successful sports clubs in Turkey with hundred thousands of fans. So, we want to measure the activities and types of social media contribution and the fans' reactions towards the team's daily activities.

\subsection{Population, Sample and Data Collection Tool}

The target population was Konyaspor Football Club's fans who follow its social media accounts. The research population was formed by the followers of the club's social media pages. In this context, there are about 228.000 people who liked the club's Facebook account; and also there are about 150.000 people following the Twitter account. The club's population was determined from the number of followers on the Facebook page. The main purpose of determining the population in this way is to calculate the sample size of the population as large as possible.

In determining the sampling of the population Yazicioglu and Erdoğan (2004)'s table was taken as reference. When sampling error is $\pm 0,05 ; \mathrm{p}=0.5$ and $\mathrm{q}=0.5$ being determined based on this formula, the expected sample size was calculated as 384 . A survey that consists of 384 questionnaires was distributed to the fans.

The primary data of this research have been collected through questionnaire. The questionnaire was composed of three parts. The first part of the questionnaire was about demographics of the respondents. The second part was about the measure that related to the social media and sports marketing. The questionnaire contained some customized demographic questions that were intended to distinguish between the Teams and the fans social media use. The adopted scale of the Sports Marketing and Social Media measurement was developed by Zerenler and Akkaya (2015). It consisted of 27 items that measure the dimensions of the sports marketing and social media. The scale of the measure was in the type of 5 points Likert scale, ranging from " 1 . Strongly disagree" to " 5 . Strongly agree".

In order to evaluate the data obtained in the research with statistical tests, This section provides the findings of the empirical research. Statistical Package for Social Science (SPSS) 23.0 was used to analyze the primary data obtained from the survey. Reliability, Frequency Distribution, Mean Standard Deviation, KMO and Barlett Test, Factor Analysis, Correlation and Regression Analyzes were performed by determining the statistical tests to be used in the data analysis when the data were coded. The Cronbach alpha coefficient was used to determine the reliability of the scales included in the survey form. 


\subsection{Hypothesis and the Model of the Study}

H1: There is a positive and statistically significant relationship between "Getting information" and "Club Licensed Product Preferences Tendency".

H2: There is a positive and statistically significant relationship between the "Communicating" and "Club Licensed Product Preferences Tendency" variables.

H3: There is a positive and statistically significant relationship between the "Sharing With" and "Club Licensed Product Preferences Tendency" variants.

H4: There is a positive and statistically significant relationship between the "Perception of Supporter" variable and the "Club Licensed Product Preference Tendency" variant.

H5: There is a positive and statistically significant relationship between the "Spending Time" and the "Club Licensed Product Preference Tendency" variant.

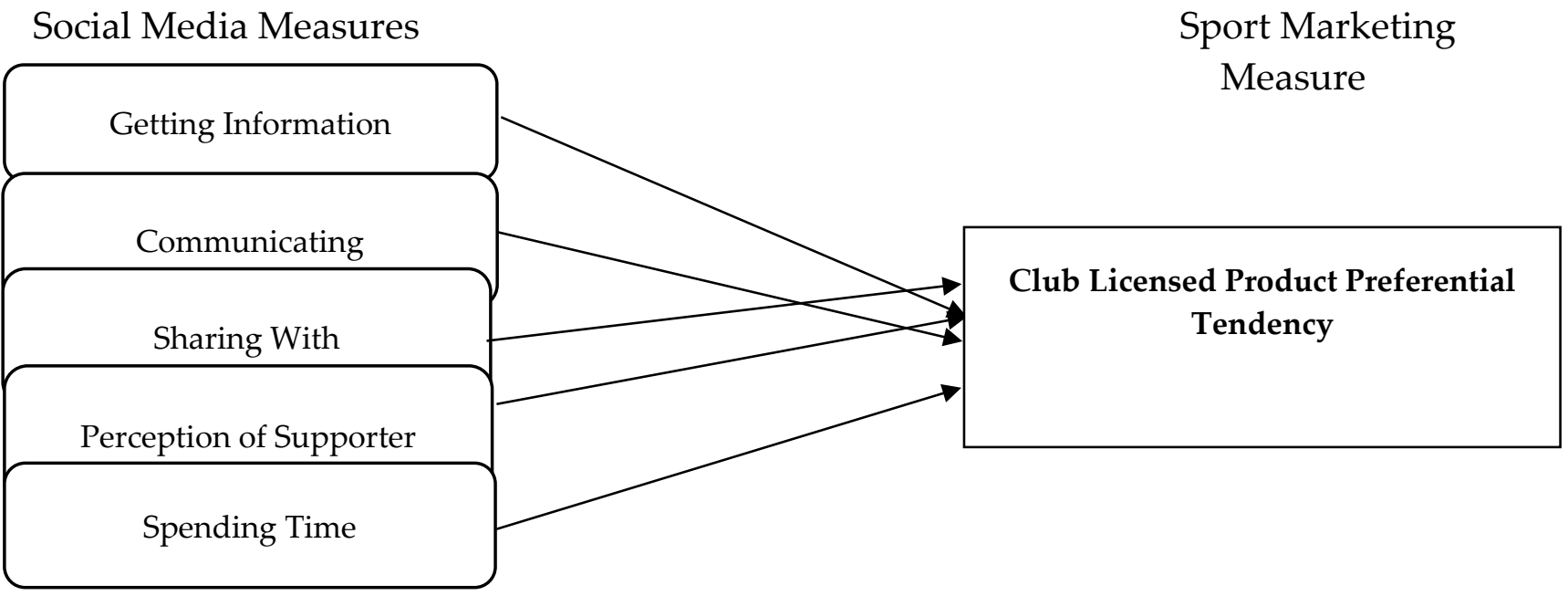

Figure 1: Research Model

\section{FINDINGS AND DISCUSSION}

According to the demographic data, majority of the respondents were male. Around half of the respondents' age fell in the 23-28 age category. The demographic data also showed that most of the respondents had bachelor's degree or went to high school. Majority of the people surveyed were students and private sector workers. When respondents asked about their income the highest average of respondents were around 0-1000 TL with high percentage. As the data revealed, a large percentage of the respondents chose Social Media as a tool of communication channel, and Facebook was the most used Social Media Platform. On the other hand, considering the expenditure of time in social media of the respondents, a large number of respondents had more than four hours.

\subsection{Dimensions Attendance Ratings for Fans}

The scale used for the research consists of six dimensions. In this part of the study participants' scale variables were examined. 
E. Şahin - M. T. Demirsel - A. A. Adam 12/1 (2020) 79-94

Table 1: Mean and Standard Deviation of the Information Dimension

\begin{tabular}{|l|c|l|c|c|}
\hline \multicolumn{2}{|c|}{ Variable } & \multicolumn{1}{|c|}{ Item } & Mean & Std. D. \\
\hline \multirow{2}{*}{} & 1 & I follow up to get transcriptions and last-minute news & 4.5 & .925 \\
\cline { 2 - 5 } & 2 & I follow to read the news about the club. & 4.4 & .981 \\
\cline { 2 - 5 } & 3 & I follow in order to reach the official statements made by the club. & 4.18 & 1.136 \\
\cline { 2 - 6 } & 4 & $\begin{array}{l}\text { I follow to get information about activities and events that the club } \\
\text { has organized. }\end{array}$ & 3.6771 & 1.399 \\
\hline \multirow{5}{*}{} & & & & \\
\hline
\end{tabular}

The first question "I follow up to get transcriptions and last-minute news" scored high mean of 4.5 and standard deviation of 0.925 . Also "I follow to read the news about the club." Came into the second with a high mean of 4.4 and also the Third question" I follow in order to reach the official statements made by the club" got a high mean of 4.18. Nevertheless, this indicates that the organization's top executives take formal responsibility for their business strategic planning.

Table 2: Mean and S. Deviation of the Club Licensed Product Preferential Tendency

\begin{tabular}{|l|l|l|r|r|}
\hline \multicolumn{2}{|l|}{ Variable } & \multicolumn{1}{|c|}{ Item } & Mean & Std. D. \\
\cline { 2 - 5 } & 2 & I follow the club to learn about product and ticket discounts. & 3.43 & 1.541 \\
\hline \multirow{2}{*}{$\begin{array}{l}\text { I follow to get information about the new licensed products of the } \\
\text { club. }\end{array}$} & 3.39 & 1.512 \\
\cline { 2 - 5 } & 3 & I am following to buy the licensed products of the club. & 3.33 & 1.553 \\
\cline { 2 - 5 } & 4 & $\begin{array}{l}\text { I follow to be aware of the promotions and competitions that your } \\
\text { club has made. }\end{array}$ & 3.24 & 1.596 \\
\cline { 2 - 5 } & 5 & $\begin{array}{l}\text { I am following to learn the combined and normal match ticket } \\
\text { information. }\end{array}$ & 3,00 & 1.569 \\
\cline { 2 - 5 } & 6 & $\begin{array}{l}\text { I follow to get information about the club's mobile app and } \\
\text { magazine. }\end{array}$ & 2.94 & 1.567 \\
\cline { 2 - 5 } & 7 & $\begin{array}{l}\text { I follow to be informed about the club's negotiated banks and } \\
\text { promotions made by the operators. }\end{array}$ & 2.60 & 1.616 \\
\hline
\end{tabular}

The above table outlines the descriptive statistics of the study. However, the means of the data items with their standard deviations are mentioned in the table. The means are listed in descending order; from the highest to lowest. Through club's product preferential dimensions "I follow the club to learn about product and ticket discounts" came into highest mean with 3.43, and also "I follow to get information about the new licensed products of the club" was the second mean score of 3.39, and the third stage was "I follow to be aware of the promotions and competitions that your club has made" with a mean of 3.33. in this dimension respondents agreed that they are intended with club's product and follow its daily activities. 
E. Şahin - M. T. Demirsel - A. A. Adam 12/1 (2020) 79-94

Table 3: Mean and Standard Deviation of Communicating Dimension

\begin{tabular}{|c|c|c|c|c|}
\hline \multicolumn{2}{|c|}{ Variable } & Item & Mean & Std. D. \\
\hline \multirow{6}{*}{ 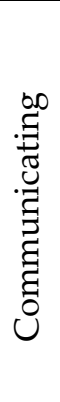 } & 1 & I follow to share the images of the grandstand. & 4.07 & 1.298 \\
\hline & 2 & I follow to share relevant information about the club. & 3.88 & 1.403 \\
\hline & 3 & I follow to be able to communicate with other fans. & 3.10 & 1.568 \\
\hline & 4 & I follow to get information about other branches of the club. & 2.99 & 1.548 \\
\hline & 5 & I follow to be able to communicate with the athletes. & 2.96 & 1.602 \\
\hline & 6 & I follow to be able to communicate with the Club. & 2.96 & 1.602 \\
\hline
\end{tabular}

In table 4, the means and standard deviation of communicating dimensions were examined, so that, "I follow to share the images of the grandstand" dimension came into the first line with a high mean of 4.7, also "I follow to share relevant information about the club" was in the second with a mean of 3.88, likewise "I follow to be able to communicate with other fans" was the third stage with a mean of 3.10. in addition, in this dimension respondents agreed that they follow and share and comment the team's social media related activities.

Table 4: Mean and Standard Deviation of Sharing Dimension

\begin{tabular}{|c|c|c|c|c|}
\hline \multicolumn{2}{|c|}{ Variable } & Item & Mean & Std. D. \\
\hline \multirow{5}{*}{ 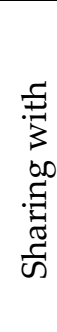 } & 1 & I follow to get information before and after the match. & 4.41 & 1.043 \\
\hline & 2 & I follow to share and read the comments about the match. & 4.40 & .997 \\
\hline & 3 & I follow to get instant information about the match. & 4.29 & 1.134 \\
\hline & 4 & I follow it to watch and share the highlights. & 3.95 & 1.291 \\
\hline & 5 & I follow to get the match and training images. & 3.85 & 1.363 \\
\hline
\end{tabular}

Respondents have given their ideas about the dimension of the above table, sharing is one of the important aims that social media is used, so the respondents agreed that "I follow to get information before and after the match" was their first aim with a high mean of 4.41 , also "I follow to share and read the comments about the match" was the second with a high mean of 4,40, in these dimensions respondents gave high mean rates that mean sharing with ideas is so important around the fans and their teams, they got information, about matches, trainings and every related information about the team.

Table 5: Mean and Standard Deviation of Perception of Support

\begin{tabular}{|l|r|l|r|r|}
\hline \multicolumn{2}{|c|}{ Variable } & \multicolumn{1}{|c|}{ Item } & Mean & Std. D. \\
\hline \multirow{3}{*}{} & 1 & I am more excited as I follow the club. & 4.38 & 1.104 \\
\cline { 2 - 5 } & 2 & As I follow the club, I feel that the feeling of supporters has been & 4.36 & 1.125 \\
\cline { 2 - 5 } & & strengthened. & & \\
\cline { 2 - 5 } & 3 & As I follow the club, I think that my attachment to the club is growing. & 4.34 & 1.147 \\
\cline { 2 - 5 } & 4 & As I follow the club, I feel myself being for the club. & 4.33 & 1.121 \\
\hline
\end{tabular}


Table 5 shows dimension of the fans and the participation ratings of the fans in these items. "I am more excited as I follow the club" was the highest mean to this dimension for the average value of 4.38, "As I follow the club, I feel that the feeling of supporters has been strengthened" was the second place with an average of 3.36. In general, when the table is examined, it is seen that the participation levels of all the materials are very high.

Table 6: Mean and Standard Deviation of Spending Time Dimension

\begin{tabular}{|c|c|c|c|c|c|}
\hline \multicolumn{3}{|c|}{ Variable } & Item & Mean & Std. \\
\hline \multirow{2}{*}{\multicolumn{2}{|c|}{ 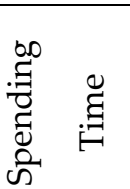 }} & 1 & I follow the club's social media accounts to spend time. & 2.67 & 1.652 \\
\hline & & 2 & $\begin{array}{l}\text { I keep track of my social media accounts when I'm bored, so I } \\
\text { can hang out. }\end{array}$ & 2.38 & 1.597 \\
\hline
\end{tabular}

Table 6 shows Spending time dimension items and participation ratings for these items. "I follow the social media accounts of the club to spend time." Got the highest mean contribution to this dimension is with an average of 2.67". And "I keep track of my social media accounts when I'm bored, so I can hang out" for a mean of 2.38. So that participants did not give very high mean ratings for this size.

Table 7:Reliability Coefficients of Scales

\begin{tabular}{|l|l|l|}
\hline Variables & $\begin{array}{c}\text { Cronbach's } \\
\text { Alpha }\end{array}$ & \multicolumn{1}{c|}{ Number of Items } \\
\hline Getting Information & 0.796 & 4 \\
\hline Club licensed product preferential Tendency & 0.917 & 7 \\
\hline Communicating & 0.835 & 6 \\
\hline Sharing with & 0.849 & 5 \\
\hline Perception of Supporter & 0.932 & 4 \\
\hline Spending Time & 0.867 & 2 \\
\hline
\end{tabular}

As can be seen in Table 7, all the scales used in the research have a high level of reliability (internal consistency). The reliability coefficients of the scales ranged from 0.79 to 0.932 . The scales used from these results appear to be highly reliable.

After this information, variables related to Social Media and Sports marketing were put together and explanatory factor analysis was performed in order to determine the factors. In the factor analysis, Kaiser-Meyer-Olkin (KMO) values were first calculated and the Bartlett's sphericity test was examined. The factor analysis is excellent when the $\mathrm{KMO}$ value is close to 1,00; If it is less than 0.50, it is regarded as bad (Kaya, 2013; 180). As shown in Table 9, the KMO value of this scale is 0.888 and is a value that can be said perfect value of scale.

Table 8: KMO and Bartlett's Test Results

\begin{tabular}{|l|l|r|}
\hline \multicolumn{2}{|l|}{ Kaiser-Meyer-Olkin Measure of Sampling Adequacy } & .888 \\
\hline \multirow{2}{*}{ Bartlett's Test of Sphericity } & Approx. Chi-Square & 8320.227 \\
\cline { 2 - 3 } & Df & 378 \\
\hline & Sig. & .000 \\
\hline
\end{tabular}


E. Şahin - M. T. Demirsel - A. A. Adam 12/1 (2020) 79-94

According to the above table, the items included in the study seem to be suitable for factor analysis (KMO: 0,888 Bartlett's Test: 8320,227 df: 378 and p: 0,00). According to these results, the factor loadings of the items are determined in Table 9.

Table 9: Factor Analysis

\begin{tabular}{|c|c|c|c|c|c|c|c|c|}
\hline & Queries & Factor 1 & Factor 2 & Factor 3 & Factor 4 & Factor 5 & Factor 6 & Explanatory \\
\hline \multirow[t]{4}{*}{ Factor 1} & S3 & .877 & & & & & & \multirow{4}{*}{64.350} \\
\hline & S19 & .741 & & & & & & \\
\hline & S4 & .867 & & & & & & \\
\hline & S2 & .711 & & & & & & \\
\hline \multirow[t]{7}{*}{ Factor 2} & S1 & & .406 & & & & & \multirow{7}{*}{68.352} \\
\hline & S5 & & .674 & & & & & \\
\hline & S6 & & .693 & & & & & \\
\hline & S7 & & .794 & & & & & \\
\hline & S8 & & .751 & & & & & \\
\hline & S9 & & .760 & & & & & \\
\hline & $\mathrm{S} 10$ & & .636 & & & & & \\
\hline \multirow[t]{6}{*}{ Factor 3} & S11 & & & .483 & & & & \multirow{6}{*}{91.974} \\
\hline & S16 & & & .835 & & & & \\
\hline & S17 & & & .885 & & & & \\
\hline & S18 & & & .650 & & & & \\
\hline & S21 & & & .684 & & & & \\
\hline & S22 & & & .783 & & & & \\
\hline \multirow[t]{5}{*}{ Factor 4} & $\mathrm{~S} 12$ & & & & .679 & & & \multirow{5}{*}{63.565} \\
\hline & S13 & & & & .499. & & & \\
\hline & S14 & & & & .757 & & & \\
\hline & S15 & & & & .644 & & & \\
\hline & S20 & & & & .598 & & & \\
\hline \multirow[t]{4}{*}{ Factor 5} & S23 & & & & & .798 & & \multirow{4}{*}{82.999} \\
\hline & S24 & & & & & .831 & & \\
\hline & S25 & & & & & .852 & & \\
\hline & S26 & & & & & .839 & & \\
\hline \multirow[t]{2}{*}{ Factor 6} & S27 & & & & & & .883 & \multirow{2}{*}{88.300} \\
\hline & S28 & & & & & & .883 & \\
\hline
\end{tabular}

As a result of the analysis using varimax rotation method, it is seen that the variables subject to research are collected in 28 items and 6 groups. In this case, it is seen that the explanation ratio for the result is $71,894 \%$ in total.

\subsection{Correlation Analysis}

Correlation values between dimensions prepared for this research are given in Table 10. The analyzes related to the table are given below. 
E. Şahin - M. T. Demirsel - A. A. Adam 12/1 (2020) 79-94

Table 10: Correlations Table

\begin{tabular}{|c|c|c|c|c|c|c|c|}
\hline & & $\begin{array}{c}\text { Getting } \\
\text { Informati } \\
\text { on }\end{array}$ & $\begin{array}{c}\text { Club L P } \\
\text { Preferent } \\
\text { ial } \\
\text { Tendenc } \\
\text { y }\end{array}$ & $\begin{array}{l}\text { Commun } \\
\text { icating }\end{array}$ & $\begin{array}{l}\text { Sharing } \\
\text { with }\end{array}$ & $\begin{array}{l}\text { Perceptio } \\
\mathrm{n} \text { of } \\
\text { Supporte } \\
\mathrm{r}\end{array}$ & $\begin{array}{l}\text { Spending } \\
\text { Time }\end{array}$ \\
\hline \multirow[t]{2}{*}{ Getting Information } & $\begin{array}{l}\text { Pearson } \\
\text { Correlation }\end{array}$ & 1 & $.549^{* *}$ & $.452^{* *}$ & $.536^{* *}$ & $.570^{* *}$ & $.152^{* *}$ \\
\hline & Sig. (2-tailed) & & .000 & .000 & .000 & .000 & .003 \\
\hline \multirow[t]{2}{*}{$\begin{array}{l}\text { Club L P preferential } \\
\text { tendency }\end{array}$} & $\begin{array}{l}\text { Pearson } \\
\text { Correlation }\end{array}$ & $.549^{* *}$ & 1 & $.656^{* *}$ & $.416^{* *}$ & $.377^{* *}$ & $.392^{* *}$ \\
\hline & Sig. (2-tailed) & .000 & & .000 & .000 & .000 & .000 \\
\hline Communicating & $\begin{array}{l}\text { Pearson } \\
\text { Correlation }\end{array}$ & $.452^{* *}$ & $.656^{* *}$ & 1 & $.587^{* *}$ & $.449^{* *}$ & $.316^{* *}$ \\
\hline Sharing with & $\begin{array}{l}\text { Sig. (2-tailed) } \\
\text { Pearson } \\
\text { Correlation }\end{array}$ & $\begin{array}{l}.000 \\
.536^{* *}\end{array}$ & $\begin{array}{l}.000 \\
.416^{* *}\end{array}$ & $.587^{* *}$ & $\begin{array}{l}.000 \\
1\end{array}$ & $\begin{array}{l}.000 \\
.549^{* *}\end{array}$ & $\begin{array}{l}.000 \\
.126^{*}\end{array}$ \\
\hline $\begin{array}{l}\text { Perception of } \\
\text { supporter }\end{array}$ & $\begin{array}{l}\text { Sig. (2-tailed) } \\
\text { Pearson } \\
\text { Correlation }\end{array}$ & $\begin{array}{l}.000 \\
.570^{* *}\end{array}$ & $\begin{array}{l}.000 \\
.377^{* *}\end{array}$ & $\begin{array}{l}.000 \\
.449^{* *}\end{array}$ & $.549^{* *}$ & $\begin{array}{l}.000 \\
1\end{array}$ & $\begin{array}{l}.013 \\
.088\end{array}$ \\
\hline \multirow[t]{2}{*}{ Spending Time } & $\begin{array}{l}\text { Sig. (2-tailed) } \\
\text { Pearson } \\
\text { Correlation }\end{array}$ & $\begin{array}{l}.000 \\
.152^{* *}\end{array}$ & $\begin{array}{l}.000 \\
.392^{* *}\end{array}$ & $\begin{array}{l}.000 \\
.316^{* *}\end{array}$ & $\begin{array}{l}.000 \\
.126^{*}\end{array}$ & .088 & $\begin{array}{l}.086 \\
1\end{array}$ \\
\hline & Sig. (2-tailed) & .003 & .000 & .000 & .013 & .086 & \\
\hline
\end{tabular}

According to the Pearson correlation analysis, there is a positive correlation (0.549) between knowledge acquisition and club product preference trend. There is a high positive correlation between communication passing and club product preference trend (0.656). There is also a positive relationship (0.416) between the presence of sharing and the club product preference trend. There is also a positive relationship (0.377) between favoritism and club product preference tendency, and there is a positive relationship (0.392) between time span and club product preference tendency. In this case, the validity of the hypotheses H1, H2, H3, H4 and H5 is accepted (Akkaya, 2015:102).

Table 11: ANOVAa Table

\begin{tabular}{|l|r|r|r|l|l|}
\hline Model & $\begin{array}{l}\text { Sum of } \\
\text { Squares }\end{array}$ & Df & $\begin{array}{l}\text { Mean } \\
\text { Square }\end{array}$ & F & P \\
\hline Regression & 345.078 & 5 & 69.016 & 92.789 & $.000 \mathrm{~b}$ \\
\hline Residual & 281.153 & 378 & .744 & & \\
\hline Total & 626.231 & 383 & & & \\
\hline
\end{tabular}

a. The dependent variable: Club licensed product preferential tendency

b. Predictors: (Constant), Spending time, perception of support, communicating, sharing with, information

When the above table is examined, it is seen that the model is generally meaningful (F: 92,789 and p: 0,000). According to this; It is statistically possible to describe the Club Licensed Product Preference Tendency dependent variable on Social Media Elements (Information, Communication, Sharing, Perception of Supporters, Time Passing) is statistically possible to explain it with at least one. 
E. Şahin - M. T. Demirsel - A. A. Adam 12/1 (2020) 79-94

Table 12: Coefficients a Table

\begin{tabular}{|c|c|c|c|c|c|c|}
\hline \multirow[t]{2}{*}{ Mod } & & \multicolumn{2}{|c|}{ Unstandardized Coefficients } & $\begin{array}{c}\text { Standardized } \\
\text { Coefficients } \\
\end{array}$ & \multirow[t]{2}{*}{$\mathrm{T}$} & \multirow[t]{2}{*}{ p. } \\
\hline & & $\mathrm{B}$ & Std. Error & Beta & & \\
\hline \multirow[t]{6}{*}{1} & (Constant) & -.718 & .246 & & -2.919 & .004 \\
\hline & Information & .501 & .065 & .347 & 7.734 & .000 \\
\hline & Communicating & .556 & .052 & .487 & 10.638 & .000 \\
\hline & Sharing with & -.098 & .066 & -.071 & -1.490 & .137 \\
\hline & Perception of support & -.021 & .056 & -.017 & -.376 & .707 \\
\hline & Spending Time & .165 & .031 & .196 & 5.379 & .000 \\
\hline
\end{tabular}

The above table shows that the Social Media aspects of examination were significant for all variables.

Regression Model: $K=-\mathbf{0 . 7 1 8}+0.501$ information +0.556 communications -0.098 sharing +0.021 perception of supporters $+\mathbf{0 . 1 6 5}$ spending time.

Table 13: : Model Summary

\begin{tabular}{|l|l|l|c|c|}
\hline Model & R & $\begin{array}{l}\text { R } \\
\text { Square }\end{array}$ & Adjusted R Square & Std. Error of the Estimate \\
\hline 1 & $.742 \mathrm{a}$ & .551 & .545 & .86243 \\
\hline
\end{tabular}

a. predictors: (constant), Information, Communication, Sharing, Perception of Supporters, Spending Time

The table above shows the Social Media Factor's explanation for the Variance of Club Licensed Product Preferences. Accordingly, it is possible to account for approximately $54.5 \%$ of the variance of the dependent club branded product preferences Tendency with the corresponding regression model (Akkaya, 2015:99).

\section{CONCLUSION}

In today's business world, the effective use of company's social media accounts is very important. Through these accounts and web pages companies can facilitate the processes of information sharing, advertising, marketing and sales. In the sports industry these practices are certainly prevalent. Sports clubs all over the world make those practices to increase their profits and satisfy their shareholders and supporters.

According to the results of the research, Konyaspor Football Club actively uses social media accounts to communicate more effectively with its supporters. As a result of the interview with the club's representative, social media has reached the conclusion that it is an important part of the marketing strategy of the club. The campaigns that Konyaspor Football Club has made with its sponsors are often shared with the fans through the social media accounts of the licensed products. However, the club is consistently sharing from social media in order to establish a closer relationship with supporters and to enhance their supporter affiliation. Basically, it can be said that sports club uses social media as a marketing, customer relations and advertising medium.

According to the results of focus groups and surveys conducted with the fans, it is possible to get information about the team's existing or new sales products, to get information about matches and tickets, to communicate with the clubs and footballers and to follow the transfer news. They follow the social media accounts of the club in order to reach the information and to reach the comments made about the club. 
The sports club is able to receive feedback from its supporters and to periodically survey the level of satisfaction and so on. Competitions may be organized to increase fans' interest in licensed products and tickets and may be encouraged by social media accounts to participate in the competition. This will increase both the interest on the club page and the fans' affection for the club. A passion for adherence plays an important role in the buying behavior process. This is why emotional and effective sharing of supportership and enthusiasm can be found. Licensed products may be shared in a way that will not hurt fans and attract attention.

According to the results of the hypothesis tests, there is a positive and significant relationship between "Information, Communication, Sharing, Perception of supporters, Spending Time factors and Club Licensed Product Preferences Tendency" factors.

Investigations can then be conducted on the supporters of the different teams in order to better understand the motivation of the followers for social media teams for subsequent research. A more thorough investigation can reveal more lasting and effective results by examining and following the fans' social media data. Investigating the buying behaviors and awareness-raising effects of sports clubs on promoting licensed products to fans through social media will contribute to a better understanding of sports marketing and social media interaction.

\section{References}

Achen, R. M. (2017). Measuring Social Media Marketing: Moving Towards a Relationship Marketing Approach. Managing Sport and Leisure, 22(1), 33-53.

Akkaya, Ö., \& Zerenler, M. (2017). Sosyal Medya ve Spor Pazarlamasi İlişkisi Taraftar Tutumlarini Belirlemeye Yönelik Bir Araştırma: Beşiktaş Spor Kulübü Örneği. Süleyman Demirel Üniversitesi İktisadi ve İdari Bilimler Fakuiltesi Dergisi, 22(4), 945-963.

Altunbaş, H. (2007). Sporun Pazarlanması ve Pazarlama İletişiminde Spor. Selçuk İletişim, 5(1), 93-100.

Argan M, \& Katırcı H., Spor Pazarlaması, Ankara: Nobel Yayın, 2002.

Blackshaw, P., \& Nazzaro, M. (2006). Consumer-Generated Media (CGM) 101 Word-of-Mouth in the Age of the WebFortified Consumer.

http://www.nielsenonline.com/downloads/us/buzz/nbzm_wp_CGM101.pdf

Chen-Olmsted, S., \& Xiao, M. (2019). Smart Sports Fans: Factors Influencing Sport Consumption on Smartphones. Sport Marketing Quarterly, 28, 181-194.

Chi, H. H. (2011). Interactive Digital Advertising vs. Virtual Brand Community: Exploratory Study of User Motivation and Social Media Marketing Responses in Taiwan. Journal of Interactive Advertising, 12(1), 4461.

Chui, M., Manyika, J., Bughin, J., Dobbs, R., Roxburgh, C., Sarrazin, \& H. Westergren, M. (2012). The social economy: Unlocking value and productivity through social technologies

Devecioğlu, S. (2005). Türkiye'de Spor Sektörü Stratejilerinin Geliştirilmesi. Verimlilik Dergisi, Sayı:2, 117-134.

Divol, R., Edelman, D., \& Sarrazin, H. (2012). Demystifying Social Media. McKinseyQuarterly, http://www.mckinsey.com/insights/marketing_sales/demystifying_social_media.

Edosomwan, S., Prakasan, S. K., Kouame, D., Watson, J., \& Seymour., T. (2011). The History of Social Media and its Impact on Business, The Journal of Applied Management and Entrepreneurship, 16(3).

Ekmekçi, R., \& Ekmekçi, Y. A. (2010). Spor Pazarlaması. Pamukkale Journal of Sport Science, 1(1), 23-29.

Goldstein, J. H. (1989). Sports, Games and Play: Social and Psychological Viewpoints (Cilt Second Edition). NY: Lawrence Erlbaum Associates.

Hambrick, M. E., \& Kang, S. J. (2014). Pin It: Exploring How Professional Sports Organizations Use Pinterest as a Communications and Relationship Marketing Tool. Communication \& Sport, 7, 1-24. 
E. Şahin - M. T. Demirsel - A. A. Adam 12/1 (2020) 79-94

Hunt, K. A., Bristol, T., \& Bashaw, R. E. (1999). A Conceptual Approach to Classifying Sports Fans. Journal of Services Marketing, 13(6), 439-452.

Johnston, W. J., Khalil, S., Le, A. N. H., \& Cheng, J. M. S. (2018). Behavioral Implications of International Social Media Advertising: An Investigation of Intervening and Contingency Factors. Journal of International Marketing, 26(2), 43-61.

Kaplan, A. M. \& Haenlein, M. (2010). Users of the World, Unite! The Challenges and Opportunities of Social Media. Business Horizons, 53(1), 59-68.

Manning, J. (2014). Socail Media, Definiton and Classes of. In K. Harvey (ed.), Encyclopedia of Social Media and Politics, Thousands Oaks, CA: Sage Publications.

Milne, G. R., \& McDonald, M. A. (1999). Sport Marketing Managing the Exchange Process. Toronto: Jones and Barlett.

Mullin, B., Hardy, S., \& Sutton, W. (2000). Sport Marketing. USA: Human Kinetics, $2^{\text {nd }}$ Edition.

Naraine, M. L. (2019). Follower Segments Within and Across the Social Media Networks of Major Professional Sport Organizations. Sport Marketing Quarterly, 28, 222-233.

Neti, S. (2011). Social Media and its Role in Marketing. International Journal of Enterprise Computing and Business Systems, 1(2), 1-16.

Ömer Akkaya, (2016), Selçuk Üniversitesi Sosyal Bilimler Enstitüsü, İşletme Ana Bilim Dalı Üretim Yönetimi ve Pazarlama Bilim Dalı, Sosyal Medya ve Spor Pazarlaması İlişkisi Taraftar Tutumlarını Belirlemeye Yönelik Bir Araştırma: Beşiktaş Spor Kulübü Örneği, Yüksek Lisans Tezi.

Pedersen, P. M., \& Thibault, L. (2014). Contemporary Sport Management. USA: Human Kinetics, Fifth Edition.

Pitts, B. G., Fielding, L. W., \& Miller, L. K. (1994). Industry Segmentation Theory and Sport Industry Developing a Sport Industry Segment Model. Sport Marketing Quarterly, 3(1), 15-24.

Rein, I., Kotler, P., \& Shields, B. (2007). İşte Taraftar İşte Marketing. (U. E. Kaplan, Çev.) İstanbul: MediaCat.

Rothschild, P. C. (2011). Social media use in sports and entertainment venues. International Journal of Event and Festival Management, 2(2), 139-150.

Safko, L. (2012). The Social Media Bible, Tactics, Tools \& Strategies For Business Success. New Jersey: John Wiley \& Sons.

Schwarz, E. C., \& Hunter, J. D. (2008). Advanced Theory and Practice in Sport Marketing. San Diego: Elsevier.

Shank, M. D., \& Lyberger, M. R. (2015). Sports Marketing A Strategic Perspective. NY: Taylor \& Francis Group.

Shilbury, D., Westerbeek, H., Quick, S., \& Funk, D. (2009). Strategic Sport Marketing. Australia.

Siddique, S., \& Singh, T. (2016). Social Media its Impact with Positive and Negative Aspects. International Journal of Computer Applications Technology and Research 5(2), 71-75.

Smith, A. (2008). Introduction to Sport Marketing. Oxford: Elsevier.

Strauss, J., \& Frost, R. (2009). E-Marketing. Saddle River, NJ: Prentice Hall.

Thompson, A. J., Martin, A. J., Gee, S., \& Eagleman, A. N. (2014). Examining the Development of a Social Media Strategy for a National Sport Organisation: A Case Study of Tennis New Zealand. Journal of Applied Sport Management, 6(2), 42-62.

Tuten, T. L. (2008). Advertising 2.0: Social Media Marketing in a Web 2.0 World. Praeger Publishers.

Vale, L., \& Fernandes, T. (2018). Social Media and Sports: Driving Fan Engagement with Football Clubs on Facebook. Journal of Strategic Marketing, 26(1), 37-55.

Wakefield, K. (2007). Team Sports Marketing. USA: Elsevier. 
E. Şahin - M. T. Demirsel - A. A. Adam 12/1 (2020) 79-94

Williams, J., \& Chinn, S. J. (2010). Meeting Relationship-Marketing Goals Through Social Media: A Conceptual Model for Sport Marketers. International Journal of Sport Communication, 3(4), 422-437.

Wysocki, M. (2012, Nisan 30). The Role of Social Media in Sports Communication: An Analysis of NBA Teams' Strategy. Yüksek Lisans Tezi. Washington, ABD: American University.

Yazıcıŏlu, Y. ve Erdoğan, S. (2004). Spss Uygulamalı Bilimsel Araştırma Yöntemleri. Ankara: Detay Yayıncılık, 4950. 